\title{
Statistical Assessment on Status of Migration and its Effect on Agricultural and Rural Development of Odisha, India
}

\author{
Abhijeet Satpathy $^{1 *}$, Subrat Kumar Mahapatra ${ }^{2}$ and Rituparna Mohapatra ${ }^{3}$ \\ ${ }^{1}$ Department of Extension Education, ${ }^{2}$ Department of Agricultural Statistics, \\ ${ }^{3}$ Department of Agricultural Economics, College of Agriculture, OUAT, India \\ *Corresponding author
}

\section{Keywords}

Migration,

Emigration,

Immigration, Rural

development,

Agriculture census

Article Info

Accepted:

15 November 2019

Available Online:

10 December 2019

\section{A B S T R A C T}

The Present Investigation was conducted on Status of migration of Odisha and its relationship with the Agricultural \& Rural development of the State. Migration is a burning socio-economic issue especially in agriculture sector and cause contraction in agricultural production. Emigration, immigration, internal migration, international migration, rural-urban migration \& seasonal migration are the different types of migrations. Agriculture \& Rural development can address the root causes of migration, including rural poverty, food insecurity, inequality, unemployment, lack of social protection as well as natural resource depletion due to environmental degradation and climate change (FAO). For conducting the research, secondary data was collected from Directorate of Economics \& Statistics, Govt. of Odisha, Odisha Agricultural Statistics Handbook, Reserve Bank of India Data \& Census of India (1991, 2001 and 2011). From the Present study it was found that more number of migrants was observed in western Part of the State viz. Bolangir and Kalahandi. Work is considered as main reason for male migrants. The Major cause of rural-urban migration for education, political and social stability, searching for job, better technologies, employment and business opportunities. Kalahandi have more number of migrants under agriculture and allied sector. Intra-state migration is also seen in this part of the state. The workers are migrated to other districts as daily wage labours in different farms, industry, brick clins. The Pattern of Migration is Seasonal in nature. The migration prone districts of Odisha Includes Bargarh, Bolangir, Kalahandi, Nuapada, Sonepur, Ganjam, Gajapati, Koraput, Nowrangpur, Koraput \& Khorda. From This Above study, it is concluded that migration significantly depends on area and production of different crops. For all the Major crops likes Cereals, Pules \& Oil Seeds crops of the state, the district having higher area \& Production attracts more migrants in 2001 and 2011 Census year. 


\section{Introduction}

Migration denotes any movement of groups of people from one locality to another and takes different forms. It is ranging from 'permanent', 'semi-permanent' and 'temporary'. Where people move for a few months in a year, the migrants are also known as 'short duration' migrants, 'seasonal' migrants or 'circulatory' migrants. It can also be termed as voluntary or forced, legal or illegal.

Survival Migration In survival migration, economic gains are minimal; there is little improvement in the economic status of both men and women. Besides, there is a reinforcement of traditional gender roles, and an increasing subordination of women. Lack of livelihood, non accessibility to governmental programmes etc lead to survival migration. The process of migration thus has a constraining effect not only in structural terms, of the choices made available, or cultural terms, but also in the sense in which it may include abuse and exploitation, and emotional and psychological distress. Poverty and search for employment have been the predominant propellants of survival migration of people.

\section{Migration in Orissa}

The economy of Orissa is predominantly agricultural and the performance in this sector is crucial to the development of the state. The prevalence of small farmers having small sized land holdings, seasonal unemployment, the non-application of modern technology in agriculture in Orissa had forced the people to search for alternate sources of livelihood. People of the rural areas migrate to urban areas within and outside their districts and also to the neighbouring states Migration is an outcome due to the repeated disasters that strike Orissa at regular intervals. Cyclones, floods, droughts and famines hit the state at different times in different regions. There have been more than 30 natural disasters during the period 1963 to 1999 . The coastal region is more prone to cyclones, floods where as the western districts and southern region are vulnerable to droughts and famines and have created a vacuum in livelihoods. The manifestations of disasters are seen in the poverty, malnutrition, distress sale of paddy, property and even children. Landlessness, indebtedness and lack of livelihood force the people to seek survival options in other far way places. Displacement is another major cause of migration in Orissa. Endowed with natural resources, Orissa is the hot destination of the multi nations and transnational companies for mining leases and industry based on them. Migration is a survival strategy in Orissa. For the landless and marginal farmers who are in constant debt, migration is the only choice for livelihood. The push arising out of lack of livelihood options in the village and indebtedness and crop loss leads to the pull factors such as the attraction of livelihood in the lean seasons. However it has been established that migration enables one just enough earning to tide over the distress in the lean season and in no way helps to accumulate capital. There is a deep linkage between migration and poverty especially of survival migration where women are found at the bottom of the pyramidal structure of poverty. Seasonal migration of Orissa Each winter season in the state of Orissa, starts a process of migration. The populace of the western districts of the state of Orissa is the ones who migrate particularly of undivided Bolangir, Koraput, Kalahandi districts (now known as the KBK districts). The phenomenon of migration is believed to have taken roots in the aftermath of severe drought of the 1960s. Today every year thousands of people across the length and breadth of the region leave their native village in search of food and employment and flock the brick kilns 
in the neighbouring state of Andhra Pradesh, the construction sites of the cities and also to the towns of the state. After the harvest there is no more work and Nuakhai or harvest related festivals bring in their own expenses for which loans are acquired and are difficult to repay.

Most end up as bonded labourers being paid minimal daily wages. Alienation of land, labour and produce is the driving force for migration. Today there is no work for more than 80 days in some parts of the region. Hence there is no other option but seek work in the brick kilns of Andhra or pull rickshaws in Raipur.

Long term migration nearly hundred thousand labourers go to Surat (Gujrat). This is a long term migration, mostly in the textile-weaving (powerloom) and diamond-polishing businesses. Though this migration has its problems, it is overall a long trend migration, with a more stable income. 5 Migration types Within the state (from one district to another district) Outside the state- Orissa to AP, Surat, Raipur Distress migration in Orissa can be categorized on the basis of the destination i.e. canal labour (agricultural wage employment in the irrigated fields of districts of Bargarh) and dadan shramika (work in the brick kilns for wage employment for $6-8$ months)

More than 30 million people in India are seasonal migrant labourers. Orissa's share is 2.5 million and considered a key state for supply of migrant labour. While remittance from migrants from Surat stands at 2000crores, every second day there are news about how migrant workers are harassed, abused and exploited in various part of India.

It is a small effort to deliberate and advocate on the issue of migration, its impact, development, policy framework and search for alternatives

\section{Migration status of India}

According to International Organization for Migration (IOM), migration is defined as the movement of a person or a group of persons, either across an international border, or within a state. It is a population movement, encompassing any kind of movement of people, whatever its length, composition and causes; it includes migration of refugees, displaced persons, economic migrants, and persons moving for other purposes, including family reunification.

IOM defined migrant as any person who is moving or has moved across an international border or within a state away from his/her habitual place of residence, regardless of (1) the person's legal status; (2) whether the movement is voluntary or involuntary; (3) what the causes for the movement are; or (4) what the length of the stay is.

Historically, information regarding migration has been collected, since 1872. Only information on place of birth and duration of residence at the place of residence were collected till 1961 by including the rural or urban status. In addition to birth place, data on the basis of place of last residence is being collected since 1971. The degree of economic and social development in both the area of origin and destination were related to different streams of migration. Migration can be classified as four streams mainly rural-rural, rural-urban, urban-rural and urban-urban. Further, stream can be intra-district, intrastate, inter-state. Majorities of the migrants are moving within the state, i.e. move within same districts or move from one district to other within the same state. Migration arises out of various social, cultural, economic, spatial and demographic reasons summarized as push and pull factors. Various theories and models were propounded to perceive the intended meaning of migration. The study of migration among 
population helps to understand the dynamics of the society. In 2018, 3.3 percent of the world's population are international migrants. Over 40 million internal migrants and more than 22 million refugees were recorded in global displacement. World estimates states that in 2013, out of 232 million international migrants 150 million people were accounted as migrant workers. The State of World Population report stated that the number of population in urban is steadily raises. As per 2011 census, urbanization in India increased from 27.81 percent in 2001 to 31.16 percent in 2011. India constitutes 11.4 million emigrants (The World Bank 2011) and 309 million internal migrants (Census of India 2001).

In 2010-11, India hits the top with 2 million people by accounting for one-fifth of all tertiary educated immigrants in OECD countries. In 2015, the immigrant population of India was 5,240,960 or 0.4 percent of total resident population and $15,573,953$ or 1.17 percent of all citizens of India lived outside their country of origin (International Organization for Migration).

\section{Status and cause of migration}

Latapi (1997) studied that the resulting demand for migrant workers provides a significant impetus to labor flows and facilitates the incorporation of undocumented migrants. Reynieri (2001) ILO research in southern European countries demonstrates the extent to which the migrants take jobs that the locals refuse. It is simply a matter of substitution. Sunny (2001) viewed that probably the number of migrant workers are larger in India than any other Asian country. Kaur(2003) studied pattern of utilization of remittances of NRIS in Doaba village of Punjab and notified that migration has great impact on economic, social, cultural and psychological life of people, both at place of emigration as well as of migration.
Araya and Roy (2005) studied Poverty, Gender and Migration and conferred that due to technological developments many women were displaced from agricultural work and economic hardships like poverty and lack of employment opportunities compelled them to migrate for survival. Shanthi (2006) examined the extent of employment oriented migration of females in India and the inter-state variations in its magnitude in his paper female labor migration in India. The extent of the independent migration is arrived at indirectly using proxy variables such as the 'never married' and 'heads'. In the north, at the disaggregated level the percentage of "never married' and "heads" is high in rural-urban and urban-urban migration and high percentage is observed in all states of south. This paper concludes by suggesting that for purposes of effective policy interventions on gender dimensions should adequately be captured in the official data system. Deshingkar and Akter (2009) revealed that construction, domestic work, textile, transportation, mines, brick-kilns, excavations and agriculture are the major sectors where migrants were mostly engaged and estimates shows that migrants contribute around 10 percent to the national GDP in his paper "Migration and Human development in India". Turrey (2009) attempted to observe growing patterns and issues of internal migration in India in relation to social and economic impacts. A crucial overview of internal migration in India shows that migration is a complex phenomenon and in spite of the vast contribution of migrants to Indian economy, social protection is still remains negligible. Chandrasekhar and Sharma (2014) studied internal migration for education and employment among youth in India and discussed that states with better job opportunity gaining at their expense but backward states are facing brain drain by losing human capital i.e. education and skill level. In all India perspective the above 
concept would not to be a problem but from the states perspective it can affect their growth trajectories and potential development. They suggested that this aspect needs to be highlighted in the discussions on inclusive growth and development. Osondu et al., (2014) study posits that migration is a socioeconomic activity which possesses implication for development, stopping migration may be futile as it has its positive implications like availability of credit for agricultural investment funds and most of the remittances should invest in productive sectors by farmers, especially in agriculture as the sector suffers more due to migration. Availability of labor for agricultural production reduces due to increase in rate of migration. Guha and Roy (2016) studied climate change, migration and food security: evidence from Indian Sundarbans and identified three factors of migration such as environment factors such as inundation of islands, coastal flooding, coastal erosion and severe cyclones etc. (86.67 percent), economic factor such as better jobs, economic benefits; land and house provided by Government etc. (33.33 percent) and social factors such as political benefits and pressure, help from relatives, religious affinity etc. (13.33 percent), which forces households to migrate directly and indirectly. Samantaray (2016) discussed the feasibility of reverse migration (urban-rural) in Odisha by applying Interpretive-Structural Model and suggested the strategy of reverse migration which helps for the growth and development of rural Odisha and ensures that both skilled and unskilled workers would be gainfully employed in the rural sector.

\section{Effect of migration in agricultural \&rural development}

Parganiha et al., (2009) studied the effect of migration of agricultural laborers on agricultural activities. It was concluded that knowledge and adoption about different agricultural practices are more in nonmigrants and also production and productivity of different crops was higher as compare to migrants. Seasonal migration was the main cause of lacking of agricultural laborers. Less mechanization caused agriculture to totally depend on manpower. That is the reason why agricultural activities and production are affected due to migration. Bagchi and Majumdar (2011) said that out migration of agricultural laborers caused a decline in the supply of laborers which indeed escalated cost of production. Kaur et al., (2011) analyzed causes and impact of labor migration in agriculture in Punjab and revealed that the major factors responsible for migration is availability of better income and employment opportunities at the destination place. Economic factors like low wages and rain-fed agriculture in the native place causes migration, while poverty, poor civic amenities, leads to poor life whereas high aspirations and demonstration effect were social and psychological factors resulting to migration. Singh (2012) analyzed the effect of migration on agricultural productivity and women empowerment in Bihar with the help of nonlinear model (Cobb-Douglas) and concluded that the contribution of remittance for agricultural inputs could have increased where proper infrastructure facilities were present in rural areas. Expansion of work load for women was observed especially in migrant households with the upcoming challenges like management of fund, technology and inputoutput marketing. Keshri and Bhagat (2013) studied the socio-economic determinants of temporary labor migration in India and observed that the two main outcomes associated with transfer of surplus labor from agriculture to non-agricultural sector is the efficiency of labor use and poverty reduction.

They observed that circular, seasonal and temporary mobility patterns are adopted by people as a part of their livelihood strategies 
and income security. Brauw (2014) explored the relationship between migration and agricultural productivity in Ethiopia using standard regression techniques and found that among young migrants, there appears to be a positive, significant relationship between productivity and households sending out a migrant.

Tuladhar et al., (2014) analyzed the effects of migration and remittances on agriculture yield in Nepal and showed two important results that migration negatively affects agriculture yield by inducing a labor shortage in the sector and no improvements in agriculture productivity in remittance-receiving agricultural households because of noninvestment of incomes on productivityenhancing agricultural capital goods and inputs.

Also suggested that allotment of remittance for agriculture productivity is important to compensate yield losses arising from labor migration. Nguyen (2015), did case study on migration, agricultural production and diversification in Vietnam and concluded that rural households who receives remittance from their migrants would increase their land productivity, shift them from rice production to other crops and also increases migrant households' specialization rather than diversification.

However, migration also decreases labor productivity and crop diversification of rural households in case of missing remittances. Venu et al., (2016) studied agricultural labor migration and remittances in Karnataka state of India and revealed that, 70 percent of intra state migration was observed in rain fed situation seasonally and total income of migrant households is higher than non-migrant households. The major proportion of income for migrant household (43 percent) was from remittance and for non-migrant households, 54 percent of income was from working as agriculture labour.

\section{Materials and Methods}

This includes the following steps

Data Collection

Statistical Analysis

It includes

Descriptive Statistics

Graphical Data Representation

Linear Regression Analysis

\section{Data collection}

The secondary data collected from Directorate of Economics \& Statistics (DOES), Govt. of Odisha, Odisha Agricultural Statistics Handbook, Reserve Bank of India Data \& Census of India $(1991,2001 \&$ 2011). Data regarding area, production and productivity of Agriculture crops were collected from Odisha Agricultural Statistics at a glance (Published by Govt of Odisha) of Different districts of Odisha.

\section{Statistical analysis}

\section{Descriptive statistics}

Collected data regarding migration, area, production and productivity were summarized and presented in the tabular form for further analysis.

By using this, we can calculate the Average Migration Workers of the state \& District level avg total migrants, avg male \& female migrants. We can also calculate the variability of Migration in different states by Using Variance. SD \& Coefficient of Variation (CV) 


\section{Graphical representation}

Graphical representation is another way of analyzing numerical data through charts and graphs by using migration data of three consecutive years 1991, 2001 and 2011 in order to know the trend of migration and distribution of migrants of different districts based on gender (male and female) and area (rural and urban).

By using Graphs, we can also interpret the total migrant workers of Odisha, total migrant worker of each state, migrants worker according to educational status/ industrial area/ economic activity /reason of migration and also we can easily calculate the trend of total migrants/female migrants/male migrants of each district of Odisha. We can also Compare the district wise agriculture \& allied activities migrant workers of different census year as comparative study.

\section{Linear regression analysis}

Linear regression is an approach for modelling the relationship between a quantitative dependent variable ( $\mathrm{Y}$ ) and one or more explanatory variables (independent variable) denoted by $X$. In present study, number of migrants of agriculture and allied sector was considered as dependent variable and area of cultivation and production as independent variables. On the other hand, productivity is considered as dependent variable and number of migrants were considered as independent.

The linear regression equation is denoted as:

$\mathrm{Y}=\alpha+\beta \mathrm{X}+\varepsilon$

Where, $\alpha$ is the intercept,

$\beta$ is the regression co-efficient,

$\varepsilon$ is the random error.
Significance of the coefficients obtained from regression analysis was interpreted using the $\mathrm{P}$-values. P-value less than 0.05 indicates that the coefficient is significant at 5\% level of significance whereas $\mathrm{P}$-value less than 0.01 indicates that the coefficient is significant at $1 \%$ level of significance.

From the above study, we can conclude that there is a continuous raise in trend of total number of migrants in Odisha from 1991to 2011. More number of migrants are observed in Western Part of the State i.e mostly in Bolangir \& Kalahandi Districts, most of the migrants are non-workers.

Participation of female as migrant workers are high in urban areas and concurrently they play major role as marginal and non-workers in rural area as well as surpassed male migrants under both literate and illiterate category in 1991, 2001 and 2011.

Male are migrating mainly for work and female are migrating more for other purposes like marriage, natural calamities, education etc. than for work. The findings concluded that for most of the crops, migration significantly depends on area and production of different crops.

The migration prone districts of Odisha Includes Bargarh, Bolangir, Kalahandi, Nuapada, Sonepur, Ganjam, Gajapati, Koraput, Nowrangpur, Koraput and Khorda. From This Above study, it is concluded that migration significantly depends on area and production of different crops.

For all the Major crops likes Cereals, Pules \& Oil Seeds crops of the state, the district having higher area and Production attracts more migrants in 2001 and 2011 Census year. The another major findings of the study is that the yield of the major crops are not significantly depended on the number of migrants. 


\section{References}

Alan Bd. 2015. Migration, Youth, and Agricultural Productivity in Ethiopia, Allied Social Science Association (ASSA) Annual Meeting, January 3-5, 2015, Boston, Massachusetts, no 189684.

Arya S and Roy A. 2006. Poverty, Gender and Migration. New Delhi: Thousand Oaks and London: Sage publication 2: 261.

Bagchi KK and Majumdar S. 2011. Dynamics of out-migration of agricultural laborers: A micro-level study in two districts of West-Bengal, Agricultural Economics ResearchReview, 24:569.

Deshingkar P and Akter S. 2009. Migration and Human Development in India, MPRA Paper: 19193, University Library of Munich, Germany, Human Development Research Papers.

Guha I and Roy C. 2016. Climate Change, Migration and Food Security: Evidence from Indian Sundarbans, International Journal of Theoretical \& Applied Sciences, 8(2): 45-49.

Hann Ad. 2011. Inclusive growth? Labour migration and poverty in India, International Institute of Social Studies, Working Paper No.513.

Kaur and Amandee. 2003. Pattern of Utilization of Remittances of NRIs in Doaba Village of Punjab. M. Phil thesis, Department of Economics, Punjabi University, Patiala.

Kaur B, Singh JM, Garg BR, Singh J and Singh S. 2011. Causes and Impact of Labour Migration: A Case Study of Punjab Agriculture,Agricultural Economics Research Review,24: 459466.

Kunal K and Bhagat RB. 2013. Socioeconomic determinants of temporary labour migration in India, Asian Population Studies, 9(2):175-195.

Latapi E. 1997. Emigration Dynamics in
Mexico, Central America and the Caribbean, 12th IOM seminar on Migration, Managing International Migration in Developing Countries, Geneva..

Nguyen, Duc Loc and Grote, Ulrike, 2015. " Migration, Agricultural Production and Diversification: A case study from Vietnam," 2015 Conference, August 9-14, 2015, Milan, Italy, no: 229379, International Association of Agricultural Economists, Pp. 1-29.

Osondu CK, Ibezim GMC, Obike $\mathrm{K}$ and Ijiomah JC.2014. Rural-urban migration, remittance economy and agricultural investment among small scale farmers in Umuahia south local government of Abia State, Nigeria, Sky Journal of Agricultural Research, 3(4): $62-66$.

Parganiha O, Sharma ML, Paraye PM and Soni VK.2009. Migration Effect of Agricultural Labourers on Agricultural Activities, Indian Research Journal of Extension Education, 9 (3): 95-98.

Patnaik BCM, Satpathy I, Mohanty J and Mandal A. 2015. Determinants of migration from Rural to Urban India by the Labourer - An Overview, Journal of Business Management \& Social Sciences Research, 4(1): 33-38.

Ponnusamy K and Sendhil R. 2015. Gender issues and livelihood pattern of migrant women labourers of farm families, Indian Journal of Agricultural Sciences, 85 (11): 14281434.

Reyneri E. 2001. Migrants' Involvement in Irregular Employment in the Mediterranean Countries of the European Union. International migration papers, no. 41, Geneva: ILO.

Samantaray LL.2016. The Feasibility of Reverse Migration in Odisha: An 
Application of Interpretive-Structural Model, Imperial Journal of Interdisciplinary Research, 2(2): 22.

Sansristi, Bhubaneswar. A Research Study On "Impact of increasing migration on Women in Orissa"

Shanthi K. 2006. Female labor migration in India: Insights from NSSO data. Working paper no. 4. http:// www.mse.ac.in.

Sharma A and Chandrasekhar S. 2014. "Internal Migration for Education and Employment among Youth in India, " Working Papers id: 5682, eSocial Sciences, http://www.igidr.ac.in/ pdf/publication/WP-2014-004.pdf.

Singh, R. and Singh, Krishna M. and Jha, A. 2012, Effect of Migration on Agricultural Productivity and Women Empowerment in Bihar, SSRN: https://ssrn.com/abstract=2111
155 or http://dx.doi.org/10.2139/ssrn.2 111155.

Singh N, Keshri Kand Bhagat RB. 2016. Gender Dimension of Migration in Urban India, India Migration Report 2015: Gender and Migration (Ed.) Rutledge, New Delhi, 176-190.

Sunny D. 2001. An enquiry into the migration of educated women of Kerala state, Ind. J. Soc. Dev. 1(1): 105-126.

Tuladhar R, Sapkota C and Adhikari, N. 2014. Effects of Migration and Remittance Income on Nepal's Agriculture Yield, ADB South Asia, working paper series no: 27 http://hdl.handle.net/11540/1287.

Venu BN, Umesh KB and Gaddi GM. 2016. Agricultural labour migration and remittances in Karnataka state of India, International Journal of Agriculture Sciences, 8(58).

\section{How to cite this article:}

Abhijeet Satpathy, Subrat Kumar Mahapatra and Rituparna Mohapatra. 2019. Statistical Assessment on Status of Migration and its Effect on Agricultural and Rural Development of Odisha. Int.J.Curr.Microbiol.App.Sci. 8(12): 1892-1900.

doi: https://doi.org/10.20546/ijcmas.2019.812.226 